\title{
Telomeraza jako potencjalny cel terapii nowotworów głowy i szyi
}

\section{Telomerase as a therapeutic target in head and neck cancer}

\author{
Dylawerska Agata ${ }^{1}$, Barczak Wojciech ${ }^{1,2}$, Suchorska Wiktoria Maria ${ }^{1,3}$ \\ ${ }^{1}$ Pracownia Radiobiologii, Zakład Fizyki Medycznej, Wielkopolskie Centrum Onkologii, ul. Garbary 15, 61-866 Poznań, Poland \\ ${ }^{2}$ Klinika Chirurgii Gtowy, Szyi i Onkologii Laryngologicznej, Wielkopolskie Centrum Onkologii, \\ Uniwersytet Medyczny $w$ Poznaniu, ul. Garbary 15, 61-866 Poznań, Poland \\ ${ }^{3}$ Katedra i Zakład Elektroradiologii, Uniwersytet Medyczny w Poznaniu, ul. Garbary 15, 61-866 Poznań, Poland
}

\begin{abstract}
Streszczenie
Telomeraza to duży, złożony kompleks enzymatyczny, który odpowiada za proces syntezy telomerów budujących zakończenia eukariotycznych chromosomów. Podwyższona ekspresja genu kodującego katalityczną podjednostkę tego enzymu - hTERT - jest obserwowana w około 88\% przypadków nowotworów rejonu głowy i szyi. Komórki rakowe zyskują wówczas wysoki potencjał replikacyjny, a także zdolność do unikania apoptozy. Zahamowanie aktywności telomerazy w terapii przeciwnowotworowej stało się priorytetem badań naukowych już kilkanaście lat temu. Istnieją różne metody wykorzystujące obniżenie ekspresji telomerazy, od terapii genowej do wykorzystania przeciwutleniaczy. Pomimo wielu danych zebranych w ostatnich latach pojawia się coraz więcej pytań w odniesieniu do roli telomerazy w powstawaniu raka. Należy przeprowadzić więcej szczegółowych badań w celu zrozumienia udziału tego enzymu w procesie rozwoju nowotworu w obrębie narządów głowy i szyi. Celem niniejszego artykułu jest zebranie dotychczasowej wiedzy na temat zastosowania telomerazy w terapii onkologicznej.
\end{abstract}

\begin{abstract}
Telomerase is an enzymatic complex catalyzing the synthesis of a telomeric DNA, building the ends of an eukaryotic chromosomes. Increased expression of the gene encoding the catalytic subunit of the enzyme - hTERT is observed in approximately $88 \%$ of head and neck cancer cases. It leads to the high replication potential and inability to respond to the signals causing apoptosis within the cancer tissues. The use of telomerase in cancer therapy become a priority research over a decade ago. There are many different strategies involving the telomerase inhibitors, gene therapy and antioxidants. Despite the large amount of data collected in recent years, there are more and more questions regarding the role of telomerase in cancerogenesis. More detailed studies must be performed in order to understand the involvement of this enzyme in the process of cancer development within the region of the head and neck.
\end{abstract}

Adres do korespondencji

mgr Wojciech Barczak

Pracownia Radiobiologii

Wielkopolskie Centrum Onkologii, ul. Garbary 15, 61-866 Poznań, Polska

Telefon.: +4861885047

e-mail: wojciech.barczak@wco.pl 
Stowa kluczowe: nowotwory głowy i szyi, telomeraza, hTERT, terapia onkologiczna

Keywords: head and neck cancer, telomerase, hTERT, cancer therapy

\section{Wstęp}

Nowotwory rejonu głowy i szyi (GiS) znajdują się na szóstym miejscu najczęściej występujących chorób nowotworowych na świecie (1). Według danych polskich z roku 2014 nowotwory GiS stanowią około 9\% wszystkich nowotworów złośliwych w populacji mężczyzn oraz około 5\% w populacji kobiet. Wznowy choroby obejmują blisko 60\% chorych, a rozwój przerzutów występuje u 20\% (1, 2). Są to guzy pochodzące $\mathrm{z}$ nabłonka jamy ustnej, gardła, języka i krtani. Nowotwory GiS dają mało charakterystyczne objawy, takie jak: ból gardła, ból i trudności w przełykaniu, niedrożność przewodów nosowych czy duszność, co wpływa także na późne diagnozowanie chorego i gorsze rokowanie (3). Czynniki ryzyka związane z rakiem rejonu głowy i szyi obejmują palenie tytoniu, alkohol i nosicielstwo wirusa HPV (wirus brodawczaka ludzkiego, ang. Human Papilloma Virus) oraz EBV (wirus Epsteina Barra, ang. Epstein Barr Virus) (4). Główną metodą terapii nowotworów GiS jest leczenie chirurgiczne, wspomagająco stosuje się promieniowanie jonizujące oraz leki cytostatyczne, a w ostatnim czasie również terapię przeciwciałami monoklonalnymi (3).

W większości przypadków nie udaje się uzyskać całkowitej remisji nowotworu. Wydaje się, że jednym z kluczowych czynników wpływających na niepowodzenie leczenia może być obecność nowotworowych komórek macierzystych (ang. cancer stem cells, CSCs), wykazujących zdolność do regeneracji i różnicowania, a także oporność na stosowane metody terapii (1). Charakteryzują się one wysoką aktywnością telomerazy, dzięki czemu mogą dzielić się bez ograniczeń. Obniżenie aktywności tego kompleksu enzymatycznego prowadzi do braku odbudowy telomerów, co skutkuje osiągnięciem limitu podziałów i zahamowaniem dalszej replikacji. W konsekwencji dochodzi do zatrzymania rozwoju tkanki nowotworowej $(5,6)$.

W publikacji przedstawiono możliwości wykorzystania telomerazy jako celu terapii nowotworów głowy i szyi.

\section{Telomeraza i telomery - budowa, funkcje}

Telomery to kompleksy DNA (kwas deoksyrybonukleinowy, ang. deoxyribonucleic acid) i białek budujące zakończenia eukariotycznych chromosomów. Składają się z krótkich, wielokrotnie powtórzonych, konserwatywnych sekwencji typu minisatelitarnego, bogatych w zasady T i G. Długość telomerów oraz kolejność zasad je budujących jest specyficzna dla każdego gatunku. U człowieka składają się z ciągu powtarzających się sekwencji 5'TTAGGG-3', a ich długość waha się od ok. 5 do $15 \mathrm{kpz}$ (kilo par zasad). Działanie ochronne przed degradacją ze strony nukleaz zapewniają między innymi białka: TRF1 (czynnik 1 wiążący się do powtórzeń telomerowych, ang. telomeric repeat binding factor), TRF2 (ang. telomeric - repeat binding factor 2) oraz POT1 (białko 1 biorące udział w ochronie jednoniciowych zakończeń telomerowych, ang. protection of telomeres 1). Białka stabilizujące strukturę kompleksu, chroniące przed niekontrolowanym łączeniem się wolnych końców łańcucha DNA to białka Rap1 - (białko 1 związane z czynnikiem Ras, ang. repressore activator protein), TPP1 (znane tez jako TINT1/PIP1/PTOP1) oraz TIN2 (jądrowy czynnik interakcji, ang. interacting nuclear factor) (7-10). Do utrzymania struktury telomerów niezbędny jest dokładny, wolny od błędów proces replikacji oraz obecność sygnałów naprawy DNA potrzebnych do zachowania stabilności genomu, a więc poprawnego funkcjonowania i żywotności komórek (11).

W 1985 roku Blackburn i Greider wykazały, że zjawisko problemu replikacji końca eukariotycznych chromosomów wymaga specjalistycznego mechanizmu utrzymującego długość telomerów (12). Główną rolę pełni w tym procesie telomeraza, która odpowiada za odbudowywanie telomerów w celu zapobiegania utraty informacji genetycznej podczas procesu replikacji. Możliwa jest również niezależna od telomerazy elongacja telomerów. Proces ten nazywa się alternatywnym wydłużaniem telomerów (ang. alternative lengthening of telomeres, ALT) i polega na ich syntezie za pomocą homologicznej rekombinacji (13). 
Telomeraza to kompleks enzymatyczny zbudowany $\mathrm{z}$ katalitycznej podjednostki o aktywności odwrotnej transkryptazy (ang. human telomerase reverse transcriptase, hTERT), matrycy RNA - hTR (ang. human telomerase RNA component) oraz białka stabilizującego strukturę całego enzymu - dyskeryny (15). Matryca hTR ma długość 450 nukleotydów. W pobliżu końca 5’ znajduje się sekwencja 5'CUAACCCUAAC-3', której centralny region jest odwrotnie komplementarny do powtarzającej się sekwencji telomerów występujących u człowieka. Telomeraza jest w stanie replikować jedynie nić bogatą w guaninę. Uważa się, że nić bogata w cytozynę jest syntetyzowana dopiero, gdy tzw. nić G jest dostatecznie wydłużona i polimeraza DNA a jest zdolna do syntezy nici komplementarnej (9). Największą aktywność telomerazy obserwuje się podczas rozwoju embrionalnego, a jej spadek związany jest z procesem starzenia. Niekontrolowany wzrost aktywności tego enzymu może prowadzić do rozwoju nowotworów. W 88\% przypadków nowotworów GiS występuje podwyższona ekspresja telomerazy (14).

\section{Telomeraza jako cel terapii nowotworów głowy i szyi}

Schemat leczenia chorych z nowotworami GiS jest zwykle prowadzony w oparciu o stopień procesu metastazy komórek rakowych oraz rozwój procesu chorobowego. Tylko u 90\% chorych w stadium I udaje się uzyskać całkowitą remisję nowotworu stosując leczenie chirurgiczne lub radioterapię. Złośliwość histologiczna nowotworu, czyli poziom podobieństwa do zdrowych, niezmienionych nowotworowo struktur wzrasta wraz ze stopniem zaawansowania procesu chorobowego i wynosi odpowiednio: 30\% w II, 50\% w III oraz 70\% w IV stadium klinicznym. W przypadku guzów o wysokim stopniu złośliwości nawrót choroby występuje szybko, a sam proces chorobowy postępuje agresywnie, ostatecznie prowadząc do śmierci (15-17).

Od lat trwają liczne badania, których celem jest wyciszenie ekspresji genu kodującego katalityczną podjednostkę telomerazy, co prowadzi do obniżenia aktywności enzymu i wyeliminowania guza (18). Rozważano wiele możliwości kontrolowania ekspresji genu hTERT w komórkach nowotworowych. Głównie obejmowały one zastosowanie inhibitorów, terapii genowej oraz immunoterapii (19).

Zahamowanie aktywności enzymatycznej z użyciem małych syntetycznych molekuł powoduje zakłócenie zdolności komórek nowotworowych do podziału. Odbywa się to bez wpływu na komórki prawidłowe, gdyż w większości przypadków nie wykazują one aktywności telomerazy (20). W badaniach in vitro wykazano, że zastosowanie BIBR-1532, niekompetycyjnego inhibitora hTERT i hTR, prowadzi do starzenia komórkowego zmniejszając proliferację komórek i długość telomerów oraz jest cytotoksyczny w wysokich dawkach (21). Komórki nowotworowe wykazujące wysoką ekspresję hTERT mogą być poddawane działaniu genów samobójczych lub onkolitycznych wirusów. Zastosowanie mają tutaj małe interferujące RNA, oligonukleotydy antysensowne lub rybozymy. GRN163L (znany również jako Imetelstat) jest najlepiej przebadanym antysensownym oligonukleotydem, który powoduje hamowanie aktywności telomerazy i skracanietelomerów w liniach komórkowych raka pochodzących z różnych narządów (22) Wykazano również, że przeciwutleniacze chronią aktywność telomerazy w komórkach prawidłowych, podczas gdy hamują w komórkach nowotworowych, lecz dokładny mechanizm tego zjawiska nie został jeszcze poznany. Antyoksydanty, takie jak NAC (N-acetylocysteina, ang. $N$-acetyl-cysteine) bezpośrednio wpływają na poziom wewnątrzkomórkowego potencjału redoks oraz reaktywnych form tlenu. Przypuszcza się, że przyczyną odwrotnego wpływu na aktywność telomerazy w odpowiedzi na leczenie NAC jest odmienna homeostaza stanu redoks w komórkach prawidłowych i nowotworowych (23). Innym podejściem do zahamowania aktywności telomerazy jest wykorzystanie białka TCAB1. TCAB1 jest elementem aktywnej telomerazy i jest wymagany $\mathrm{w}$ procesie gromadzenia się holoenzymu telomerazy w ciałkach Cajala, ziarnistościach obecnych w jądrach komórkowych komórek proliferujących oraz w procesie wydłużania telomerów (24). Spadek poziomu TCAB1 skutkuje obniżeniem proliferacji komórkowej i aktywności telomerazy w komórkach nowotworowych rejonu głowy i szyi (25). Immunoterapia prowadząca do obniżenia aktywności telomerazy opiera się na wykorzystaniu genu hTERT i może być stosowana w przypadku wielu nowotworów złośliwych. Podczas badań przeprowadzonych $\mathrm{w}$ warunkach in vitro i in vivo zaobserwowano regresję nowotworu po podaniu szczepionki. Fragmenty 
peptydów powstałe po degradacji telomerazy mogą być prezentowane na powierzchni komórek nowotworowych cytotoksycznym limfocytom T CD8+ przez główny kompleks zgodności tkankowej klasy I (ang. major histocompatibility complex, MHC I), co prowadzi do stymulacji układu immunologicznego i atakowania komórek wykazujących ekspresję telomerazy. Dodatkowo, aktywacji mogą ulegać także limfocyty T pomocnicze (CD4+), odpowiedzialne za utrzymanie i wzmacnianie odpowiedzi immunologicznej. Na chwilę obecną GV1001, GRNVAC1 oraz VX-001 są najbardziej obiecującymi dostępnymi szczepionkami. [20] W badaniach wykonanych przez Zhao i wsp. (2014) zaobserwowano, że celecoxib, inhibitor COX2 (cyklooksygenaza 2, ang. cyclooxygenase 2) wykazujący działanie przeciwzapalne powoduje aktywację apoptozy orazzahamowanie cyklu komórkowego i aktywności telomerazy poprzez wpływ na białka Bax (białko X związane z Bcl-2, ang. Bcl-2-associated „X protein), Bcl-2 (białko chłoniaka B-komórkowego, ang. B-cell lymphoma 2)ihTERT mRNA wkomórkach rakakrtani(26)W przypadku terapiiopartych o miRNA, cząsteczek odpowiedzialnych za regulacjęekspresjigenów, potencjalnezastosowaniew terapii ma miR-512-5P.Wykazano, że spełnia on funkcje genu supresorowego w stosunku do hTERT. W komórkach raka płaskonabłonkowego rejonu głowy i szyi podwyższona ekspresja miR-512-5P związana była z aktywacją apoptozy, inhibicją aktywności telomerazy, spadkiem poziomów białek wiążących telomery oraz skracaniem długości telomerów (27) 1a,25-Dihydroksywitamina D3 jest czynnikiem przeciwnowotworowym badanym w wielu testach klinicznych, lecz jej zastosowanie w terapii jest ograniczone efektami ubocznymi, jakie wywołuje, między innymi hiperkaliemią. MART-10 (ang. 19-nor-2a-(3-hydroxypropyl)-1a,25-Dihydroxyvitamin D3), analog tego związku powoduje znacznie mniej stanów niepożądanych przy jednoczesnym zachowaniu skuteczności terapeutycznej. W badaniach wykonanych u chorych z nowotworem GiS wykazano, że zastosowanie MART-10 prowadzi do zahamowania rozwoju tkanki nowotworowej poprzez zatrzymanie cyklu komórkowego w fazie G1, czemu towarzyszy wzrost aktywności białek p21 i p27 oraz spadek aktywności telomerazy (28). Zastosowanie w hamowaniu telomerazy znajdują także wirusy onkolityczne. Telomelizyna (OBP-301) to zmodyfikowany adenowirus typu 5 posiadający w swoim genomie promotor hTERT, który kontroluje ekspresję genów wirusowych E1A i E1B, odpowiedzialnych za proces replikacji. Podczas aktywacji promotora cały aparat komórkowy syntetyzujeprzedewszystkimbiałkawirusowe, coprowadzido onkolitycznejśmiercikomórek. Lek jest dobrze tolerowany przez chorych, co wykazano podczas I fazy badań klinicznych. Największą skuteczność terapeutyczną obserwuje sięprzy podaniu miejscowym, gdyżwprowadzeniebezpośrednio dokrwiobiegu może powodować degradację wektorów wirusowych przez białka układu dopełniacza (29). Waghorn i wsp. (2017) zbadali skuteczność zastosowania inhibitorów telomerazy: BIBR-1532, flawnoidu (2-(3,4-dihydroksyfenylo)7,8-dihydroksy-4H-chromen-4-one) i MST-312 wyznakowanych izotopem ${ }^{123}$ I w terapii nowotworów z miejsca przerzutu - jamy opłucnej. Zaobserwowano następujące wyniki: 1) ${ }^{123}$ I-BIBR-1532 został wychwycony przez komórki w niewielkim stopniu; 2) flawonoid wykazywał dobrą cytotoksyczność, lecz był niestabilny w surowicy; 3) ${ }^{123}$ I-MST-312 został pobrany przez komórki, posiadał dobrą stabilność oraz wykazywał działanie toksyczne w stosunku do komórek nowotworowych (30). Dodatkowo, zahamowanie hTERT prowadzi do wzrostu wrażliwości na chemioterapię komórek nowotworowych rejonu głowy i szyi poprzez wpływ na ścieżkę sygnalizacyjną AKT/ERK. Zastosowanie leczenia opartego na wyciszeniu aktywności telomerazy w połączeniu $\mathrm{z}$ konwencjonalną chemioterapią może być więc atrakcyjnym podejśsiem w terapii nowotworów GiS, opornych na stosowane metody leczenia (31).

\section{Wnioski}

Ekspresja telomerazy jest podwyższona w wielu nowotworach złośliwych, istnieje więc silna korelacja pomiędzy poziomem ekspresji i aktywności telomerazy a procesem nowotworzenia. Na szczególną uwagę zasługuje również duża różnica pomiędzy aktywnością tego enzymu w komórkach prawidłowych i rakowych. Różnica ta jest znacznie wyższa od tej obserwowanej w enzymach będących celem chemioterapii, takich jak syntetaza tymidynalowa czy reduktaza dihydrofolianowa. Inhibitory telomerazy wykazują dobrą selektywność dla komórek nowotworowych przy minimalnej toksyczności dla prawidłowej tkanki. Niemniej jednak w planowaniu schematu leczenia należy uwzględnić potencjalny wpływ na aktywność enzymu w komórkach prawidłowych organizmu, w tym w komórkach macierzystych, aby uniknąć działań niepożądanych. Istnieje wiele różnych strategii terapii wykorzystującej inhibicję telomerazy, od terapii genowej do wykorzystania przeciwutleniaczy i szczepionek. Najważniejszym celem obecnie prowadzonych badań jest opracowanie 
skutecznych metod wprowadzenia tych molekuł przy jednoczesnym zachowaniu bezpieczeństwa, specyficzności i skuteczności terapeutycznej oraz ograniczeniu efektów ubocznych. Wyżej przedstawione przykłady przeprowadzonych doświadczeń potwierdzają hipotezę o możliwości zahamowania rozrostu tkanki nowotworowej i spadku masy guza poprzez inaktywację telomerazy. Dodatkowo połączenie tej metody leczenia z terapią konwencjonalną potęguje efekt terapeutyczny. Nadal nie wyjaśniono jednak roli telomerazy w powstawaniu raka. Należy przeprowadzić więcej szczegółowych badań w celu zrozumienia udziału tego enzymu w procesie kancyrogenezy, który wydaje się wychodzić poza zwiększony potencjał replikacyjny i być wymagany w procesie metastazy.

\section{Wkład autorów / Authors' contributions}

Agata Dylawerska:

- zasadniczy wkład w koncepcję i projekt pracy,

- zebranie danych i interpretacja,

- zebranie piśmiennictwa.

Wiktoria M. Suchorska:

- krytyczne zrecenzowanie pod kątem istotnej zawartości intelektualnej,

- akceptacja ostatecznej wersji do opublikowania.

Wojciech Barczak:

- krytyczne zrecenzowanie pod kątem istotnej zawartości intelektualnej.

\section{Konflikt interesu / Conflict of interest}

Nie występuje / None

\section{Finansowanie / Financial support}

Niniejsza praca jest finansowana ze środków Narodowego Centrum Nauki nr 2015/17/N/NZ5/oo686.

\section{Etyka / Ethics}

Treści przedstawione w artykule są zgodne z zasadami Deklaracji Helsińskiej, dyrektywami EU oraz ujednoliconymi wymaganiami dla czasopism biomedycznych. 


\section{Piśmiennictwo / References}

[1] Méry B, Guy JB, Espenel S, Wozny AS, Simonet S, Vallard A, et al. Targeting head and neck tumoral stem cells: From biological aspects to therapeutic perspectives. World J Stem Cells. 2016;8(1):13-21. doi: 10.4252/wjsc.v8.i1.13.

[2] Polskie Towarzystwo Onkologiczne. Obecny Stan Zwalczania Nowotworów w Polsce. 16 maja 2014 roku. pp:17-20 https://pto.med.pl/content/download/7709/8440o/file/Obecny_Stan.pdf. Dostęp: 23 October 2016.

[3] Haines GK (2013) Pathology of Head and Neck Cancers I: Epithelial and Related Tumors. In: Radosevich JA (ed). Head and Neck Cancer: Current Perspectives, Advances and Challenges. Springer Science \& Business Media, Dordrecht, pp:257-87.

[4] Klein JD, Grandis JR. The molecular pathogenesis of head and neck cancer. Cancer Biol Ther. 2010;9(1):17.

[5] Prince ME, Sivanandan R, Kaczorowski A, Wolf GT, Kaplan MJ, Dalerba P, et al. Identification of a subpopulation of cells with cancer stem cell properties in head and neck squamous cell carcinoma. Proc Natl Acad Sci USA. 2007;104: 973-978.

[6] Wicha MS, Liu S, Dontu G. Cancer stem cells: an old idea-a paradigm shift. Cancer Res. 2006;66: 18831890.

[7] Pfeiffer V, Lingner J. Replication of telomeres and the regulation of telomerase. Cold Spring Harb Perspect Biol. 2013;5(5): a010405.

[8] Masood A. Shammas. Telomeres, lifestyle, cancer and aging. Curr. Opin. Clin. Nutr. Metab Care. 2011;14(1):18-34.

[9] Sandin S, Rhodes D. Telomerase structure. Curr Opin Struct Biol. 2014;25(100):104-110.

[10] Lu W, Zhang Y, Liu D, Songyang Z, Wan M. Telomeres-structure, function, and regulation. Exp Cell Res. 2013; 319(2):133-41.

[11] de Lange T. How telomeres solve the end-protection problem. Science. 2009;326:948-952.

[12] Greider C.W., Blackburn E.H. Identification of a specific telomere terminal transferase activity in Tetrahymena extracts. Cell. 1985;43:405-413.

[13] Cesare AJ, Reddel RR. Alternative lengthening of telomeres: models, mechanisms and implications. Nat Rev Genet. 2010;11(5):319-30. doi: 10.1038/nrg2763.

[14] Kunická Z, Mucha I, Fajkus J. Telomerase activity in head and neck cancer. Anticancer Res. 2008;28(5B):3125-9.

[15] Forastiere A, Koch W, Trotti A, Sidransky D. Head and neck cancer. N Engl J Med. 2001;345:1890-1900.

[16] Choong N, Vokes E. Expanding role of the medical oncologist in the management of head and neck cancer. CA Cancer J Clin. 2008;58:32-53.

[17] Kanazawa T, Misawa K, Misawa Y, Uehara T, Fukushima H, Kusaka G, et al. G-protein-coupled receptors: Next generation therapeutic targets in head and neck cancer? Toxins (Basel). 2015;7:2959-2984.

[18] Kelland LR. Overcoming the immortality of tumour cells by telomere and telomerase based cancer therapeutics--current status and future prospects. Eur J Cancer. 2005;41(7):971-9.

[19] Mocellin S, Pooley KA, Nitti D. Telomerase and the search for the end of cancer. Trends Mol Med. 2013;19:125-133. doi:10.1016/j. molmed.2012.11.006.

[20] Vinagre J, Pinto V, Celestino R, Reis M, Pópulo H, Boaventura P, et al. Telomerase promoter mutations in cancer: an emerging molecular biomarker? Virchows Arch. 2014;465:119-133. doi: 10.1007/soo428014-1608-4

[21] Damm K, Hemmann U, Garin-Chesa P, Hauel N, Kauffmann I, Priepke H, et al. A highly selective telomerase inhibitor limiting human cancer cell proliferation. EMBO J. 2001;20:6958-6968. doi:10. 1093/emboj/20.24.6958.

[22] Buseman CM, Wright WE, Shay JW. Is telomerase a viable target in cancer? Mutat Res. 2012;730:90-97.

[23] Li P, Wu M, Wang J, Sui Y, Liu S, Shi D. NAC selectively inhibit cancer telomerase activity: A higher redox homeostasis threshold exists in cancer cells. Redox Biol. 2015;8:91-97. doi: 10.1016/j.redox.2015.12.001.

[24] Venteicher AS, Artandi SE. TCAB1: driving telomerase to Cajal bodies. Cell Cycle. 2009;8(9):1329-31.

[25] Sun CK, Luo XB, Gou YP, Hu L, Wang K, Li C, et al. TCAB1: a potential target for diagnosis and therapy 
of head and neck carcinomas. Mol Cancer. 2014;13:180. doi: 10.1186/1476-4598-13-180.

[26] Zhao YQ, Feng HW, Jia T, Chen XM, Zhang H, Xu AT, et al. Antiproliferative effects of celecoxib in Hep-2 cells through telomerase inhibition and induction of apoptosis. Asian Pac J Cancer Prev. 2014;15(12):4919-23.

[27] Li J, Lei H, Xu Y, Tao ZZ. miR-512-5p suppresses tumor growth by targeting hTERT in telomerase positive head and neck squamous cell carcinoma in vitro and in vivo. PLoS One. 2015;10(8):e0135265. doi: 10.1371/journal.pone.0135265.

[28] Chiang KC, Yeh CN, Hsu JT, Chen LW, Kuo SF, Sun CC, et al. MART-10, a novel vitamin D analog, inhibits head and neck squamous carcinoma cells growth through cell cycle arrest at Go/G1 with upregulation of p21 and p27 and downregulation of telomerase. J Steroid Biochem Mol Biol. 2013;138:427-34. doi: 10.1016/j.jsbmb.2013.09.002.

[29] Takahashi H, Hyakusoku H, Horii C, Takahashi M, Nishimura G, Taguchi T, et al. Telomerase-specific oncolytic adenovirus: antitumor effects on radiation-resistant head and neck squamous cell carcinoma cells. Head Neck. 2014;36(3):411-8. doi: 10.1002/hed.23309.

[30] Waghorn PA, Jackson MR, Gouverneur V, Vallis KA. Targeting telomerase with radiolabeled inhibitors. Eur J Med Chem. 2017;125:117-129. doi: 10.1016/j.ejmech.2016.09.028.

[31] Zhao T, Hu F, Liu X, Tao Q. Blockade of telomerase reversetranscriptase enhances chemosensitivityin head and neck cancers through inhibition of AKT/ERK signaling pathways. Oncotarget. 2015;6(34):3590821. doi: 10.18632/oncotarget.5468. 